\title{
AN INDIVIDUAL'S PSYCHOLOGICAL AUTONOMY AND WARM RELATIONS WITH OTHERS AND THEIR INFLUENCE ON THE FEELING OF HAPPINESS
}

In Happiness And Contemporary Society : Conference Proceedings Volume (Lviv, March, 20-21, 2021). Lviv: SPOLOM, 2021. P. 65-67. https://doi.org/10.31108/7.2021.12

ISBN 978-966-919-697-2

\section{ПСИХОЛОГІЧНА АВТОНОМІЯ ОСОБИСТОСТІ ТА ТЕПЛИМИ СТОСУНКАМИ 3 ІНШИМИ ТА ÏХ ВПЛИВ НА ВІДЧУТТЯ ЩАСТЯ}

// Щастя та сучасне суспільство : збірник матеріалів міжнародної наукової конференції (Львів, 20-21 березня 2021 р.). - Львів : СПОЛОМ, 2021. С. 65-67. https://doi.org/10.31108/7.2021.12

ISBN 978-966-919-697-2 
https://doi.org/10.31108/7.2021.12

\author{
CHAIKA Galina
}

PhD in Psychologcial Science

G.S. Kostiuk Institute of Psychology, National Academy of Educational Sciences

(Kyiv, Ukraine)

\title{
AN INDIVIDUAL'S PSYCHOLOGICAL AUTONOMY AND WARM RELATIONS WITH OTHERS AND THEIR INFLUENCE ON THE FEELING OF HAPPINESS
}

Autonomy and positive relationships with others are two factors that influence people's belief that they have a choice and are able to choose their life path based on own goals, beliefs and values, and, in addition, they are able and want to interact flexibly with the social environment, and this is what supports their psychological well-being. The thesis demonstrates that there are some personal traits that support both personal autonomy and the ability to create and maintain positive relationships with other people. That is, these needs are not mutually exclusive, but rather complement each other, making a person's life pain colourful and multifaceted. It is clear that not only autonomy in actions and deeds and not only positive relationships are the key to happiness. Happiness is a complex phenomenon that depends on many factors, both external and internal, but experienced autonomy and positive relationships are its components.

KEY WORDS: autonomy, positive relationships with others, psychological wellbeing, happiness.

ЧАЙКА Галина

канд. психол. наук

Інститут психологї імені Г.С.Костюка Національної Академії педагогічних наук (Київ, Україна)

\section{ПСИХОЛОГІЧНА АВТОНОМІЯ ОСОБИСТОСТІ ТА ТЕПЛИМИ СТОСУНКАМИ З ІНШИМИ ТА ЇХ ВПЛИВ НА ВІДЧУТТЯ ЩАСТЯ}

Потреба в автономії як бажання діяти на основі власних переконань, ідей, мотивів задля досягнення власних життєвих цілей - це основа способу життя у постмодерністському суспільстві, це головна цінність такого суспільства. Проте існує й інша, певною мірою протилежна, потреба - у прив'язаності до інших, що означає бажання людини мати надійні, довірливі, теплі стосунки з іншими людьми, відчувати надійні родинні зв'язки, мати друзів, загалом бути приналежною до певної групи людей, малої чи великої - це вже інше питання. В епоху постмодернізму на перший план виходить індивідуальність людини, дуальні поняття свій-чужий, правда-брехня стають більш розмитими, залежними не від загально прийнятих поглядів, а від кута зору певної людини. Тому кожна людина все більше і більше починає сприймати себе як окрему одиницю, не залежну, не пов'язану із суспільством, до якого в неї немає справи і жодних зобов'язань. I лише потреба у прив'язаності до рідних і близьких, у позитивних взаєминах 3 
іншими не дає людині перейти межу від відносної автономії, як бажання нести відповідальність за власне життя, до абсолютної автономії егоїста.

Саме потреба у прив'язаності до інших, до приналежності до певних суспільних груп, до створенні і підтримки позитивних відносин з людьми поряд дає змогу суспільству залишатися суспільством, тобто людською єдністю, що само-організується задля досягнення цілей важливих для всіх, а людині як особистості відчувати себе психологічно благополучною, духовно гармонійною і в цілому щасливою.

Автономія та прив'язаність до інших - це два фактори, яки впливають на віру людини у те, що вона має вибір і здатна вибирати свій життєвий шлях, виходячи з власних цілей, переконань i цінностей, i, крім того, вона здатна, вміє i бажає гнучко взаємодіяти із соціальним середовищем, і саме це підтримує психологічне благополуччя людини.

В межах широкої тематики вивчення детермінант психологічного благополуччя, що досліджується у лабораторії психології особистості Інституту психології імені Г.С.Костюка, автором цих тез вивчалися два фактори шестифакторної моделі психологічного благополуччя, запропонованої К.Рифф, а саме показники позитивних взаємин $з$ іншими та автономії. В пропонованих тезах стисло надані попередні результати дослідження, 3 особливим наголосом на взаємозв'язок цих показників із показниками щастя.

Отримані емпіричні дані показали, що, якщо людина здатна створювати позитивні взаємини з іншими, то такі стосунки вибудовуються на вірі у себе, у власні сили, здібності, енергію, на відчутті самостійності, схвалені себе, впевненості у своїй цікавості для інших. Респонденти, які мають позитивні взаємини до інших здані сприймати себе та інших, зокрема, своїх партнерів, такими, як вони $\epsilon$, ставитися до них позитивно, довіряти ним, бачити в них особистість. Люди в високими показниками позитивних взаємин з іншими мають високу життєстійкість, вони здані впоратися у складних стресових ситуаціях, вони готові діяти, щоб подолати перешкоди, достягти мети і вийти оновленими із складної ситуації. Ці люди ставляться до майбутнього з оптимізмом, а також позитивно ставляться до фізичних контактів. Вони схильні позитивно оцінювати своє минуле, тобто власний досвід вони оцінюють як такий, який сприяє їх розвитку i $\epsilon$ основою для теперішнього їх стану. Вони високо оцінюють власну самоефективність, впевнені і здатності організувати та реалізувати діяльність задля досягнення певної мети. Вони спираються на внутрішню орієнтацію, як на здатність самостійно і свідомо вибирати лінію вибраної поведінки; характеризуються відчуттям компетентності, впевненістю у власних діях, адекватно реагують на зміни у оточенні.

I найголовніше, вони відчувають задоволення від життя, яке вони ведуть, вважають, що якість їх життя висока, відчувають щастя. Баланс афекту їх позитивний, що означає, що вони відчувають переважно позитивні емоції, значно частіше, ніж негативні.

Респонденти 3 високим показником автономії, так само як i ті, хто має позитивні взаємини з іншими, здатні ефективно діяти у складних стресових ситуаціях, щоб подолати перешкоди, достягти мети. Так само вони вірять у себе, у свої сили , емоційно приймають себе, їх можна описати як людей, які сприймають 
своїх партнерів, інших людей як особистостей, в їх неповторності, такими які вони $\epsilon$; вони так само вірять у власну самоефективність, як потенційну здатність ефективно вирішувати різні не прості ситуації.

Респонденти 3 високим показником автономії вірять у свої теперішні досягнення i, при цьому, з оптимізмом очікують на майбутні можливості, здатні приділяти достатній час як собі, так і іншим. Таких респондентів можна описати як активних людей, які отримають задоволення від фізичних навантажень і активного відпочинку; людей, які, за потреби, здатні до саморефлексії, проте не схильні до фантазування; людей, які «легко» ставляться до грошей і речей. Вони схильні демонструвати свою думку досить часто, щиро і відкрито, проте без нав'язливості; вони внутрішньо готові виконати те, що вони пообіцяли зробити, незалежно від зовнішнього контролю; вони здатні узгоджувати доцільність власних вчинків із власними інтересами, схильностями, нормами і поглядами; проте вони здатні бути і зухвалими, вступати до конфліктів.

Наголосимо, що респонденти 3 високою автономією відчувають частіше позитивні емоції, ніж негативні, i, в цілому, сприймають своє життя як щасливе.

Отримані результати показують, що існує низка особистісних рис, які підтримують як здатність до особистісної автономії, так і здатність створювати і підтримувати позитивні стосунки 3 іншими людьми. Тобто ці потреби не $є$ взаємовиключними, а скоріше доповнюють одна одну, роблячи життя людини біль кольоровим і багатогранним.

Зрозуміло, що не лише автономія у діях і вчинках і не лише позитивні взаємини є запорукою щастя. Щастя - складний феномен, що залежить від великої кількості чинників, як зовнішніх так і внутрішніх, проте автономія і позитивні взаємини є іï складовими. 